\title{
WORKING MEMORY ROLE ON GENDER TOWARDS LANGUAGE TRANSFER: STUDY OF NEUROLINGUISTICS
}

\author{
Sofia Marwati ${ }^{1}$ \\ 1(Linguistics Program, Andalas University/sofidnl@gmail.com) \\ Gusdi Sastra ${ }^{2}$ \\ ${ }_{2}^{2}$ (Andalas University/sastrabudaya84@gmail.com)
}

\begin{abstract}
Second language acquisition requires many aspects including how the working memory supports the system of the human input system. Working memory has a crucial identity in storing information for a short time. It is a limited complex ability required for holding and manipulating information in a brief period for learning, thinking, giving attention, counting, memorizing, comprehending, and problem-solving. The aims of this research are to predict the role of working memory capacity on males and females and to identify the language transfer in between. The subject of this research consisted of 14 Indonesian students (7 male 7 female) at International Islamic University Malaysia (IIUM). They are signed as postgraduate students of many different majors. Data were taken by using the reading span test of Ronnberg version. Data were analyzed by referring to Baddeley, Hitch, and Ellis. The finding of the research declares that difference gender has different working memory capacity pattern and language transfer. Gender is also a crucial factor in improving second language acquisition.
\end{abstract}

Keywords:

Working Memory Capacity; Bilingual; Indonesian Student; Language Transfer

DOI: $10.19105 /$ ojbs.v13i2.2566

\section{A. Introduction}

Mastering more than one language is not an option. Many fields of different categories require second language mastery such as job vacancy, bussiness, and education. More than half of world population is bilingual. The term of bilingual in this study refers to Indonesian and English. This study departs from the fact that English proficiency of Indonesian is below average. ${ }^{1}$ Indonesia is in rank 51 out of

\footnotetext{
1 "Kemampuan Bahasa Inggris Warga Indonesia di Bawah Rata-Rata | Republika Online,"
}

88 countries in the world. Indonesian ranking has remained in the low proficiency level since 2017 and still remains below the rank of other ASEAN countries, such as Singapore (68.63) at the very high skill level, the Philippines (61.84) and Malaysia (58.32) at the high skill level.

Study between bilingual and the brain function has been more interested

accessed December 14, 2018,
https://www.republika.co.id/berita/nasional/umum/ 18/12/14/pjq0na349-kemampuan-bahasa-inggriswarga-indonesia-di-bawah-ratarata. 
in the recent time. Chomsky notices that a person's language in all its aspects is a state of some components of the mind. ${ }^{2}$ Working memory capacity in bilingual brain is one of the examples. Working memory is a memory store of a very limited capacity that holds information for a few second ${ }^{3}$ and other cognitive tasks such as reading, problem solving or learning. ${ }^{4}$ Working memory can be ilustrated when someone acquaints new vocabularies. New information will stay in someone's brain lastly 45 minutes. Working memory is important for reasoning and the guidance of decision-making and behavior. $^{5}$

Baddeley and Hitch identifies three components of WM. ${ }^{6}$ First, Phonologcal loop stores information in the form of sounds that allow for articulation exercises. It occurs within a limited time span (approximately 2 seconds). Second, visual scatchpad is used in temporary memories and manipulates

2 Noam Chomsky, Language and Mind (Cambridge: Cambridge University Press, 2006).

${ }^{3}$ Eynseck in Rod Ellis, The Study of Second Language Acquisition, 2nd ed. (Oxford: Oxford University Press, 2006), 650.

4 Alan D. Baddeley, "Working Memory," in Psychology of Learning and Motivation, vol. 8, Phil. TrNA. R. Soc. Lond. B302 (New York: Academic Press, 1983), 311-24, https://doi.org/10.1016/S0079-7421(08)60452-1.

${ }^{5}$ Adele Diamond, "Executive Functions," Annual Review of Psychology 64, no. 1 (January 2, 2013): 135-68, https://doi.org/10.1146/annurevpsych-113011-143750.

${ }^{6}$ Alan D. Baddeley and Graham Hitch, "Working Memory," in Psychology of Learning and Motivation, ed. Gordon H. Bower, vol. 8 (New York: Academic Press, 1974), 47-89, https://doi.org/10.1016/S0079-7421(08)60452-1. spatial and visual information. Third, central executive is also the crucial component. Its role includes selective attention to certain stimuli while ignoring others, temporary activation of long-term memory, and resolution of potential conflicts between schemes. ${ }^{7}$

Benefit of having good working memory capacity has been improved by previous researches. Some of them are Bergsleithne ${ }^{8}$ and Tavares $^{9}$ who similarly found that WM are having sgnificant correlations to L2 performance both in spontanious and planned condition. Another research conducted by Service et al states that aspects of sentence comprehension in foreign language develop with practice. ${ }^{10}$ It means that the participants use WM ability and maximize them into long-term memory.

In addition, linguists from various countries have examined the capacity of working memory from various objects such as Speck et al, ${ }^{11}$ meta-analysis

7 Ellis, The Study of Second Language Acquisition, 2006, 651.

8 Joara Martin Bergsleithner, "The Role of Noticing and Working Memory Capacity in L2 Oral," in Organon, Porto Alegre, $N^{2} 51,2011,217-$ 43, https://doi.org/10.22456/2238-8915.28841.

9 Maria da Glória Guará-Tavares, "Working Memory Capacity and L2 Speech Performance in Planned and Spontaneous Conditions: A Correlational Analysis," Trabalhos Em Linguística Aplicada 52, no. 1 (June 2013): 09-29, https://doi.org/10.1590/S0103-

18132013000100002.

10 Elisabet Service et al., "Bilingual Working Memory Span Is Affected by Language Skill," European Journal of Cognitive Psychology 14, no. 3 (July 2002): 383-408, https://doi.org/10.1080/09541440143000140.

${ }^{11}$ Oliver Speck et al., "Gender Differences in the Functional Organization of the Brain for Working 
research by Hill et al, ${ }^{12}$ working memory research on aphasia by Majerus. ${ }^{13}$ The researches have been carried out with the help of $f M R I$ in order to clearly see the differences in working memory network. Weaknesses in the study are the findings only in the form of working memory network images. It is not supported by the capacity of working memory. The research only focuses in one point of view.

Language transfer based on Ellis refers to any feature of first language influence the use and acquisition of second language. ${ }^{14}$ There are some categories of language transfer, they are errors (negative transfer), facilitation (positive transfer), avoidance (or underproduction), and over-use. Errors is occurred as a result of lack of knowledge (lack of competence). Facilitation or positive transfer means that first language can facilitate second language learning. It occurs when there are similarities between first and second language. Avoidance occurs because of

Memory:," NeuroReport 11, no. 11 (August 2000): 2581-85, https://doi.org/10.1097/00001756200008030-00046.

${ }^{12}$ Ashley C. Hill, Angela R. Laird, and Jennifer L. Robinson, "Gender Differences in Working Memory Networks: A BrainMap Meta-Analysis," Biological Psychology 102 (October 2014): 1829,

https://doi.org/10.1016/j.biopsycho.2014.06.008.

${ }^{13}$ Steve Majerus, "Working Memory Treatment in Aphasia: A Theoretical and Quantitative Review," Journal of Neurolinguistics, Short-term and working memory deficits in aphasia: Current issues in theory, evidence, and treatment, 48 (November 1, 2018): 157-75, https://doi.org/10.1016/j.jneuroling.2017.12.001.

14 Ellis, The Study of Second Language Acquisition, 2006, 351. differences between native language and the target language. Over-use occurs as a result of intralingual process such as over-generalization.

Research related to language transfer also has been conducted previously, such as Karim and Nassaji, ${ }^{15}$ Alahmadi and Kesseiri ${ }^{16}$ and Utami and Malihah. ${ }^{17}$ The researches focus on evidence of language transfer. There is no explanation of the brain connection and gender difference.

By saying so, a research to perceive working memory role on gender toward language transfer is urged to conduct, language transfer in this study includes two things, namely positive and negative transfer. It refers to Ellis. ${ }^{18}$

By knowing the relationship between the two, it provides new information about the lack of Indonesian understanding of English. This information can be useful for English institutions, teachers, and parents to gain more success in second language learning. Therefore, Neurolinguistics

\footnotetext{
15 Khaled Karim and Hossein Nassaji, "First Language Transfer in Second Language Writing: An Examination of Current Research," Iranian Journal of Language Teaching Research 1, no. 1 (January 2013): 117-34.

${ }^{16}$ Nasreen Saud Alahmadi and Radia Kesseiri, "Language Transfer and Grammatical Speaking Errors among Saudi Students," Arab World English Journal 4, no. 3 (2013): 251-65.

17 Agustina Ridho Utami and Noor Malihah, "Speech Errors Produced by EFL Learners of Islamic Boarding School in Telling English Story," OKARA: Jurnal Bahasa dan Sastra 12, no. 2 (November 30, 2018): 191-200, https://doi.org/10.19105/ojbs.v12i2.1930.

18 Ellis, The Study of Second Language Acquisition, 2006.
} 
based research is deemed necessary in order to provide solution for Indonesian to improve their second language skills.

\section{B. Method}

This research is aimed to analyze working memory role on gender towards language transfer. It is a descriptive research which is qualitatively done.

Subjects of the research were 14 Indonesian students at International Islamic University Malaysia (ISUM). They are signed as postgraduate students of many different majors. Category of post graduate has been chose due to the optimal age for brain function. ${ }^{19}$

Data were collected by asking participant to do several things. First, they were asked to fill the questionnaires to be categorized based on their conditional background such as age, major, score of English proficiency, etc. Second, they were asked to do Reading Span Test based on Ronnberg et al version. ${ }^{20}$ Participants were shown some slides consisted of several sentences to analyze. One is to identify whether the sentence made sense or not. Two is to recall the first or last word of each

\footnotetext{
19 "Umur Berapa Otak Manusia Berkembang Optimal?," accessed September 30, 2019, https://health.detik.com/berita-detikhealth/d1528647/umur-berapa-otak-manusiaberkembang-optimal.

20 Jerker Rönnberg et al., "Visual Evoked Potentials: Relation to Adult Speechreading and Cognitive Function," Journal of Speech and Hearing Research 32, no. 4 (December 1, 1989): 725-35, https://doi.org/10.1044/jshr.3204.725.
}

sentence. The answer sheets were provided. It was measured using total correct method. Each correct word and yes/no response were written on the given answer sheet. Third, they were asked to transfer 26 Indonesian sentences into English. They are given several stimuli words before transferring in order to support and disrupt their memories.

Data analysis was done qualitatively and considering some of related literatures such as Hakim who found capacity of Indonesian students' memory capacity in Japanese major. ${ }^{21}$ Tavares who also succesfully found that there are significant correlations between working memory capacity and accuracy in spontaneous conditions and there are also significant correlations between working memory capacity, fluency and complexity in planned conditions. ${ }^{22}$

Finally, data analysis is explained by using charts and tables. It is supported by verbal elaboration which refers to theories by Baddeley and Hitch, ${ }^{23}$ Ellis ${ }^{24}$ and Sastra. ${ }^{25}$

21 Ruri Fadhilla Hakim, “Interferensi Dalam Bahasa Jepang Ditinjau Dari Kapasitas Working Memory Otak: Suatu Kajian Neurolinguistik" (Thesis, Andalas University, 2015).

22 Guará-Tavares, "Working Memory Capacity and L2 Speech Performance in Planned and Spontaneous Conditions," 1.

${ }^{23}$ Baddeley and Hitch, "Working Memory."

24 Rod Ellis, The Study of Second Language Acquisition (New York: Oxford University Press, 1994).

${ }^{25}$ Gusdi Sastra, Neurolinguistik Suatu Pengantar (Bandung: Alfabeta, 2010). 


\section{Results}

1. Working Memory capacity of Male Participant

Working memory leads people to focus and gives attention. Every individual person has their own working memory capacity. Working memory capacities based on reading span test result are shown in the below tables.

Table 1

Working Memory capacity for male

\begin{tabular}{ccccccccc}
\hline \multirow{2}{*}{$\mathrm{ML}$} & \multicolumn{1}{l}{ Participants (n: 14) } \\
\cline { 2 - 9 } & $\mathrm{L}$ & $\%$ & $\mathrm{M}$ & $\%$ & $\mathrm{AM}$ & $\%$ & $\mathrm{H}$ & $\%$ \\
\hline 3ss & 0 & 0 & 0 & 0 & 5 & 71.4 & 2 & 28.6 \\
4ss & 0 & 0 & 2 & 28.6 & 4 & 57.1 & 1 & 14.3 \\
5 ss & 0 & 0 & 0 & 0 & 7 & 100 & 0 & 0 \\
6ss & 0 & 0 & 1 & 14.3 & 6 & 85.7 & 0 & 0 \\
\hline
\end{tabular}

(ss: sentences), (ML: memory load, L: low, M: moderate, AM: above moderate, $\mathrm{H}$ : high, ss: sentences)

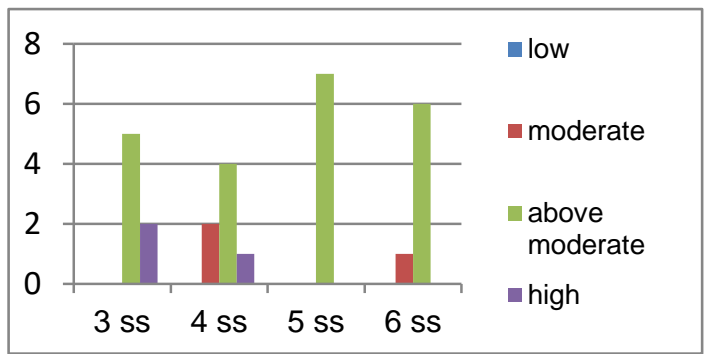

Fig. 1. Working Memory capacity for male

Reading span test has been succesfully identified male participants. Seven students were required to follow the test. Three sentences was the first memory load given to the participants. Two participants are typed of having high working memory capacity (28.6\%). It is proved by having 15 and 15.5 numbers of correct asnwers out of 18 $\mathrm{Y} / \mathrm{N}$ and recall test. Five students are categorized having above moderate.

Working memory capacity is $(71.4 \%)$ with the number of correct answers 10 to 12.5 out of $18 \mathrm{Y} / \mathrm{N}$ and recall test. There is no student categorized having low working memory capacity.

Second, 4 sentences were given as the next level of memory load. The result shows that only one participant successfully circled as having high working memory capacity (14.3\%). Total amount of correct answers are 19 out of $24 \mathrm{Y} / \mathrm{N}$ and recall test. Four students are grouped having above moderate working memory capacity (57.1\%). Total amount of correct answer are between 14.5 to 16 out of $24 \mathrm{Y} / \mathrm{N}$ and recall test. Two students are categorized having moderate working memory capacity (28.6\%). Total number of correct answers are 10 and 11.5 out of $24 \mathrm{Y} / \mathrm{N}$ and recall test. There is no student categorized having low working memory capacity.

Third, the upper level of given memory load is 5 sentences. It appears that all participants are grouped having above moderate working memory capacity $(100 \%)$. Total amount of correct answers are between 15 to 20.5 out of 30 $\mathrm{Y} / \mathrm{N}$ and recall test. There is no student categorized having low, moderate and high working memory capacity.

The last one is 6 sentences as the highest level of given memory load. It shows that six participants are circled having above moderate working memory capacity $(85.7 \%)$. Total amount of correct answers are between 18.5 to 20 out of $36 \mathrm{Y} / \mathrm{N}$ and recall test. One participant categorized having moderate working memory capacity (14.3\%). Total amount of correct answers are 18 out of 
$36 \mathrm{Y} / \mathrm{N}$ and recall test. There is no participant categorized having low and high working memory capacity.

\section{Working Memory capacity of Female Participant}

Table 2

Working Memory capacity for female

\begin{tabular}{ccccccccc}
\hline \multirow{2}{*}{$\mathrm{ML}$} & \multicolumn{1}{c}{ Participants (n: 14) } \\
\cline { 2 - 9 } & $\mathrm{L}$ & $\%$ & $\mathrm{M}$ & $\%$ & $\mathrm{AM}$ & $\%$ & $\mathrm{H}$ & $\%$ \\
\hline 3ss & 0 & 0 & 0 & 0 & 6 & 85.7 & 1 & 14.3 \\
4ss & 0 & 0 & 0 & 0 & 7 & 100 & 0 & 0 \\
5ss & 0 & 0 & 1 & 14.3 & 6 & 85.7 & 0 & 0 \\
6ss & 0 & 0 & 0 & 0 & 7 & 100 & 0 & 0 \\
\hline
\end{tabular}

(ss: sentences) (ML: memory load, L: low, M: moderate, AM: above moderate, $\mathrm{H}$ : high, ss: sentences)

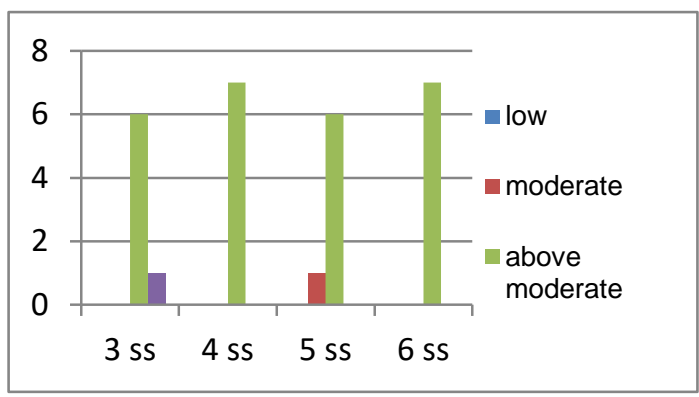

Fig. 2. Working Memory capacity for female

Compared to male participants, female ones have been also succesfully identified using reading span test. Reading span test is a working memory capacity test that mentioned by Ellis ${ }^{26}$, this finding is also supported by Hakim where he emphasizes over the result of Indonesian students in Japanese major. ${ }^{27}$

Data show female category of their working memory capacity. First, three

26 Ellis, The Study of Second Language Acquisition, 2006.

27 Hakim, "Interferensi dalam Bahasa Jepang Ditinjau dari Kapasitas Working Memory Otak: Suatu Kajian Neurolinguistik." sentences were given as a memory load. One participant is typed of having high working memory capacity (14.3\%). It is proven by having 14 numbers of correct asnwers out of $18 \mathrm{Y} / \mathrm{N}$ and recall test. Six students are categorized having above moderate working memory capacity $(85.7 \%)$ with the number of correct answers are between 11.5 to 13.5 out of $18 \mathrm{Y} / \mathrm{N}$ and recall test. There is no student categorized having low and moderate working memory capacity.

Second, 4 sentences were given as the next level of memory load. The result shows that all participants are grouped having above moderate working memory capacity (100\%). Total amount of correct answers are between 12.5 to 18 out of 24 $\mathrm{Y} / \mathrm{N}$ and recall test. There is no student categorized having low, moderate, and high working memory capacity.

Third, the upper level of given memory load is 5 sentences. It appears that six participants are grouped having above moderate working memory capacity $(85.7 \%)$. Total amount of correct answers are between 18 to 19.5 out of $30 \mathrm{Y} / \mathrm{N}$ and recall test. One participant is circled having moderate working memory capacity (14.3\%). Total amount of correct answers are 14.5 out of $30 \mathrm{Y} / \mathrm{N}$ and recall test. There is no student categorized having low and high working memory capacity.

The last one is 6 sentences as the highest level of given memory load. It shows that all participants are grouped having above moderate working memory capacity (100\%). Total amount of correct 
answers are between 20 to 25 out of 36 $\mathrm{Y} / \mathrm{N}$ and recall test. There is no student categorized having low, moderate, and high working memory capacity.

\section{Language Transfer of Male Participant}

\section{a. Errors}

It has been found several errors of male participant, such as ommission, substitution, and error in sentence structure.

Omission occurs in the following data. (e.g., 'My little sister wear red cap', 'Sometimes he only eat a piece of bread,' 'Yogyakarta has many tourism object to be visited,' 'There is a lot of place to visit in Yogyakarta,' 'Yogyakarta has many tourist destination that can be visited,' 'Yogyakarta has many tourism spot which can be visited,' 'The book that Andy read seem interesting,' 'In Japan, society like to walk,' 'In Japan, society prefer to walk,' 'That computer belong to my friend's parents').

Participants tend to omit suffix $-\mathrm{s}$ after single pronoun. It happens based on the rule of first language which has no changes among verbs (there is no subject-verb agreement).

Omission error also occurs in sentence (e.g., this machine created by Indonesian student). Participant ommit "is" as the form of passive voice.

Other errors are: (e.g., 'Some elementary school is not able to read,' 'Every house have its own aroma,'
'The doctor who came at yesterday party was beautiful,' 'The doctor who comes to the party yesterday is pretty,' 'Paul use his shoes, the red car and expensive its broke,' 'Last night the rain fallen heavy,' 'Last night the rain fall heavily,' 'Book that is read by Andy seems interested').

Participants tend to substitute several words into another. It changes the meaning and breaks the grammar. The changes are has > have, is > was, came > comes, wear $>$ use, broken > broke, fell > fallen, fell $>$ fall, interesting $>$ interested.

The reasons for those errors are the lack of participants' knowledge in choosing the suitable words for each meaning. This result is exactly supporting the previous researches such as Marwati, ${ }^{28}$ Jam et $a l,{ }^{29}$ and Leung and Brice ${ }^{30}$ which identify the errors and its explanation.

In addition, error also occurs in the level of sentence structure such

28 Sofia Marwati, "An Analysis of ErrorPronouncing Phonemes Caused by Interference as Found in Spoken English of the First Year Students at the English Department of Andalas University and Some Universities in Melbourne" (Thesis, Universitas Andalas, 2016).

29 Bashir Jam, Masood RahimiDomakani, and Zahra Asghari Kasegari, "An Intralingual Analysis of Iranian EFL Learners' Difficulties Caused by the Inconsistency between Spelling and Pronunciation," International Journal of Educational Investigations 1, no. 1 (2014): 13447.

${ }^{30}$ Cynthia Leung Leung and Alejandro Brice, "An Analysis of Phonological Processes Involved in Spoken English of Hong Kong Primary PreService Teachers," Language Testing in Asia 2, no. 2 (May 2012): 1-18, https://doi.org/10.1186/2229-0443-2-2-42. 
as. (e.g., Tadi malam hujan turun dengan derasnya is transferred as Last night was heavy rain. Masih banyak orang yang salah dalam memakai vitamin rambut is transferred as still many people are wrong in using hair vitamin. Saya sangat membenci ketombe is transferred as I very hate dendrouf).

The patterns of sentences are still following Indonesian. It clearly means that first language gives big influence to the second language use.

\section{b. Facilitation (positive transfer)}

There are several positive transfers that successfully found in data ('Paul wears red hat,' 'Bill Gates gives $\$ 350.000$ for charity').

Most participants succeed to produce those sentences. First language helps them to make it happen since the sentence structure of Indonesian and English is quite similar.

\section{c. Avoidance}

The data of over-use are as follow. ('A bread has been produced to replace a piece of bread,' Let us home has been produced to replace let's go home,' 'Really excited has been produced to replace is really excited').

It might occur because of the limitation of participants' knowledge.

\section{d. Over-use (over generalization)}

A participant over-generalize the use of suffix -s, (e.g., 'Many people likes orchid,' 'It rains heavily last night,' 'The doctor who comes to party is beautiful').

Suffix $-s$ tends to be used in any type of tenses. It happens as a result of intralingual process. Other overuse data are: ('In Japan, citizen prefer to walk on foot,' 'Many people like anggrek flower,' 'The car that colour red and expensive price is broken,' 'Many people doing mistake in order using vitamin hair.' 'Sometimes he eat pieces of bread).'

In this case, participants use the pattern of Indonesian into English. Last datum is required to write single noun instead of plural. The participants over-use it.

\section{Language Trasfer of Female Participant}

\section{a. Errors}

It also has been found several errors of female pasrticipant, such as ommission, substitution, and error in sentence structure. Omission occurs in the following data ('Sometimes he just eat a bread,' 'Yogyakarta has many tourism place to visited.' 'Yogyakarta offers many tourist attraction,' 'Yogyakarta has many tourism area to visit.' 'Many student of primary school cannot read,' 'In Japan, the society prefer to walk).'

Participants tend to omit suffix $-\mathrm{s}$ after single pronoun. It happens based on the rule of first language which has no changes among verbs (there is no subject-verb agreement). 
Omission error also occurs in sentences such as: ('Yogyakarta has many tourism places to visited.') Participant omit "be" as the form of passive voice. ('This machine made by Indonesian student'). Participant omit "is" as the form of passive voice.

Another data for error are: ('Expensive red car was broke,' 'The red car which is expensive brokes,' 'Red car is pricey and it is broke,' 'My room have the same wide with my mother's room,' 'The doctor coming to the party last night was beautiful,' 'The doctor who went to the party yesterday was pretty').

Participants tend to substitute several words into another. It changes the meaning and breaks the grammar. The changes are: is > was, is broken > brokes, is broken $>$ is broke, has $>$ have, is $>$ was.

The reasons for those errors are the lack of participants' knowledge in choosing the suitable words for each meaning.

In addition, addition error is found in female, such as (e.g., selfie is my uncle hobbies). Participant add suffix -s of the word hobby as a plural marker. In fact, the sentence doesn't need singular form instead of the plural one.

Error also occurs in the level of sentence structure such as Tadi malam hujan turun dengan derasnya are tranfered as at night was there heavy rain, tonight was heavy rain. last night was heavy rain, yesterday night, heavy rained, last night was raining heavily.

The patterns of sentences are still following Indonesian. It clearly means that first language gives big influence to the second language use.

\section{b. Facilitation (positive transfer)}

There are several positive transfers that successfully found in data which are similar to male ('Paul wears red hat,' 'Bill Gates gives $\$ 350.000$ for charity').

Most of participants succeed to produce those sentences. First language helps them to make it happen since the sentence structure of Indonesian and English is quite similar.

\section{c. Avoidance}

There is only one datum for overuse category. a bread has been produced to replace a piece of bread. It might occur because of the limitation of participants' knowledge.

\section{d. Over-use (over generalization)}

Over-use data are found as follow: ('Many people like orchid flower,' 'Family is a children first school'). Participants use the pattern of Indonesian into English. The last datum of the world children should be single noun.

\section{Conclusion}

Working memory capacity between male and female has significant differences. Working memory capacity of 
male tends to do not have pattern, while female inclines to have the same pattern. Language transfer data has also different results for both genders. Male are having more negative transfer than female. It relies on fact that female are better in language comprehension than male. Then, male has different system of brain which needs more physical activities and big space. It is also supported by the different working memory capacity. It inclines that male has unpredicable pattern which closely related to the teaching strategies. Female stands on a same capacity of working memory. Both of them need different ways to be taught on.

\section{References}

Alahmadi, Nasreen Saud, and Radia Kesseiri. "Language Transfer and Grammatical Speaking Errors among Saudi Students." Arab World English Journal 4, no. 3 (2013): 251-65.

Baddeley, Alan D. "Working Memory." In Psychology of Learning and Motivation, 8:311-24. Phil. TrNA. R. Soc. Lond. B302. New York: Academic Press, 1983. https://doi.org/10.1016/S00797421(08)60452-1.

Baddeley, Alan D., and Graham Hitch. "Working Memory." In Psychology of Learning and Motivation, edited by Gordon $\mathrm{H}$. Bower, 8:47-89. New York: Academic Press, 1974. https://doi.org/10.1016/S00797421(08)60452-1.
Bergsleithner, Joara Martin. "The Role of Noticing and Working Memory Capacity in L2 Oral." In Organon, Porto Alegre, N²51, 217-43, 2011. https://doi.org/10.22456/22388915.28841.

Chomsky, Noam. Language and Mind. Cambridge: Cambridge University Press, 2006.

Diamond, Adele. "Executive Functions." Annual Review of Psychology 64, no. 1 (January 2, 2013): 135-68. https://doi.org/10.1146/annurevpsych-113011-143750.

Ellis, Rod. The Study of Second Language Acquisition. New York: Oxford University Press, 1994.

- The Study of Second Language Acquisition. 2nd ed. Oxford: Oxford University Press, 2006.

Guará-Tavares, Maria da Glória. "Working Memory Capacity and L2 Speech Performance in Planned and Spontaneous Conditions: A Correlational Analysis." Trabalhos Em Linguística Aplicada 52, no. 1 (June 2013): 09-29. https://doi.org/10.1590/S010318132013000100002.

Hakim, Ruri Fadhilla. "Interferensi Dalam Bahasa Jepang ditinjau dari Kapasitas Working Memory Otak: Suatu Kajian Neurolinguistik." Thesis, Andalas University, 2015.

Hill, Ashley C., Angela R. Laird, and Jennifer L. Robinson. "Gender Differences in Working Memory Networks: A Brain Map Meta- 
Analysis." Biological Psychology 102 (October 2014): 18-29. https://doi.org/10.1016/j.biopsych o.2014.06.008.

Jam, Bashir, Masood Rahimi Domakani, and Zahra Asghari Kasegari. "An Intralingual Analysis of Iranian EFL Learners' Difficulties Caused by the Inconsistency between Spelling and Pronunciation." International Journal of Educational Investigations 1, no. 1 (2014): 134-47.

Karim, Khaled, and Hossein Nassaji. "First Language Transfer in Second Language Writing: An Examination of Current Research." Iranian Journal of Language Teaching Research 1, no. 1 (January 2013): 117-34.

"Kemampuan Bahasa Inggris Warga Indonesia di Bawah Rata-Rata | Republika Online." Accessed December 14, 2018. https://www.republika.co.id/berita /nasional/umum/18/12/14/pjq0na 349-kemampuan-bahasa-inggriswarga-indonesia-di-bawahratarata.

Leung, Cynthia Leung, and Alejandro Brice. "An Analysis of Phonological Processes Involved in Spoken English of Hong Kong Primary Pre-Service Teachers." Language Testing in Asia 2, no. 2 (May 2012): 1-18. https://doi.org/10.1186/2229-

0443-2-2-42.

Majerus, Steve. "Working Memory Treatment in Aphasia: A Theoretical and Quantitative Review." Journal of
Neurolinguistics, Short-term and working memory deficits in aphasia: Current issues in theory, evidence, and treatment, 48 (November 1, 2018): 157-75. https://doi.org/10.1016/j.jneurolin g.2017.12.001.

Marwati, Sofia. "An Analysis of ErrorPronouncing Phonemes Caused by Interference as Found in Spoken English of the First Year Students at the English Department of Andalas University and Some Universities in Melbourne." Thesis, Universitas Andalas, 2016.

Rönnberg, Jerker, Stig Arlinger, Björn Lyxell, and C Kinnefors. "Visual Evoked Potentials: Relation to Adult Speechreading and Cognitive Function." Journal of Speech and Hearing Research 32, no. 4 (December 1, 1989): 725-35. https://doi.org/10.1044/jshr.3204. 725.

Sastra, Gusdi. Neurolinguistik Suatu Pengantar. Bandung: Alfabeta, 2010.

Service, Elisabet, Marjut Simola, Oili Metsänheimo, and Sini Maury. "Bilingual Working Memory Span Is Affected by Language Skill." European Journal of Cognitive Psychology 14, no. 3 (July 2002): 383-408. https://doi.org/10.1080/09541440 143000140.

Speck, Oliver, Thomas Ernst, Jochen Braun, Christoph Koch, Eric Miller, and Linda Chang. "Gender Differences in the Functional 
Organization of the Brain for Working Memory:" NeuroReport 11, no. 11 (August 2000): 258185.

https://doi.org/10.1097/00001756 -200008030-00046.
"Umur Berapa Otak Manusia Berkembang Optimal?" Accessed September 30, 2019. https://health.detik.com/berita- detikhealth/d-1528647/umur- berapa-otak-manusia- berkembang-optimal.

Utami, Agustina Ridho, and Noor Malihah. "Speech Errors Produced by EFL Learners of Islamic Boarding School in Telling English Story." OKARA: Jurnal Bahasa dan Sastra 12, no. 2 (November 30, 2018): 191200.

https://doi.org/10.19105/ojbs.v12i 2.1930. 